\title{
GENDER INEQUALITY IN HEALTHCARE IN TERMS OF EMPLOYMENT AND REMUNERATION: LEGAL MEANS OF OVERCOMING THE PROBLEM
}

DOI: 10.36740/WLek202012218

\author{
Olena Y. Kostiuchenko' ${ }^{1}$, Olha V. Hots-Yakovlieva², Julia 0. Sayenko ${ }^{2}$ \\ 'DEPARTMENT OF LEGAL ENSURING OF BUSINESS SECURITY, KYIV NATIONAL UNIVERSITY OF TRADE AND ECONOMICS, KYIV, UKRAINE \\ ${ }^{2}$ DEPARTMENT OF CIVIL LAW DISCIPLINES AND LABOUR LAW NAMED AFTER PROF. OII. PROTSEVSKIY, H.S. SKOVORODA KHARKIV NATIONAL \\ PEDAGOGICAL UNIVERSITY, KHARKIV, UKRAINE
}

\begin{abstract}
The aim: To determine the nature of gender inequalities in the field of healthcare according to the criteria of employment and remuneration and to outline legal means to overcome this problem.

Materials and methods: Reports of international organizations (World Health Organization, International Labour Organization, Organization for Economic Cooperation and Development); Ukrainian non-governmental organizations' reports and statistics of the State Statistics Service of Ukraine. The study is based on theoretical and empirical methods. Conclusions: To overcome the problems associated with gender inequality in healthcare, we need to use legal means intended to implement the concept of decent work for women who work in the medical profession. This concept should include: removing barriers of women's employment in healthcare, support to women's careers and gender parity on management positions at healthcare facilities; establishing the minimum wage of healthcare employees at the level of the average wage in the country; creation of a specific entity (e.g. commission) to consider cases of gender discrimination against women in the healthcare sector; establishing salary bonuses for women-healthcare employees who have children, and other legal mechanisms.
\end{abstract}

KEY WORDS: healthcare employees, women, gender inequality, employment, remuneration

Wiad Lek. 2020;73(12 p. II):2810-2815

\section{INTRODUCTION}

The World Health Organization assumes that there will be a global shortage of healthcare employees (about 18 million people) by 2030 due to number of demographic and economic transformations [1]. According to the World Health Organization, this shortage can be mitigated by initiatives to establish gender equality in healthcare [2]. The implementation of such initiatives should be carried out through the establishment of legal means aimed to eliminate the factors that produce gender inequality in the field of healthcare. Especially such factors can be identified on the criteria of the level of employment and remuneration of women who hold medical positions. The scientific attention of such researchers and authors as V. Pashkov, V. Tatsiy, N. Gutorova [3], A. Hempenstall, J. Tomlinson, M. Bismark [4], S. Ludwig, C. Kurmeyer, M. Gross [5], D. Barr [6], E. Spencer, A. Deal, N. Pruthi [7], L. Willett, A. Halvorsen, S. Chaudhry [8], S. Read, R. Butkus, A. Weissman [9] was drawn to the importance of these and adjacent issues. The outcomes of their studies revealed gender inequality in the field of healthcare, which confirms the relevance of this article, which aims to outline the most problematic issues of gender inequalities in the field of healthcare and to outline legal means to overcome this problem.

\section{THE AIM}

The article is to define problems of gender inequalities in healthcare in terms of employment and remuneration and to outline legal means to overcome this problem

\section{MATERIALS AND METHODS}

The study conducted on the basis of analysis of reports of international organizations (World Health Organization, International Labour Organization, Organization for Economic Cooperation and Development), reports of Ukrainian non-governmental organizations and statistical data of the State Statistics Service of Ukraine. The data that reports on gender inequalities in healthcare covers 104 countries and the period between 1993 and 2020. To identify comparable characteristics of gender inequality in healthcare, the following medical professions were considered: physicians and nurses. To assess gender issues the following indicators were used: the distribution of health employees by gender, age, position, nature of employment (employment in the private or public healthcare sector) and wages.

The study is based on theoretical and empirical methods. Theoretical methods included content analysis of the data from the reports of international organizations and scientific literature. Empirical methods related to processing 


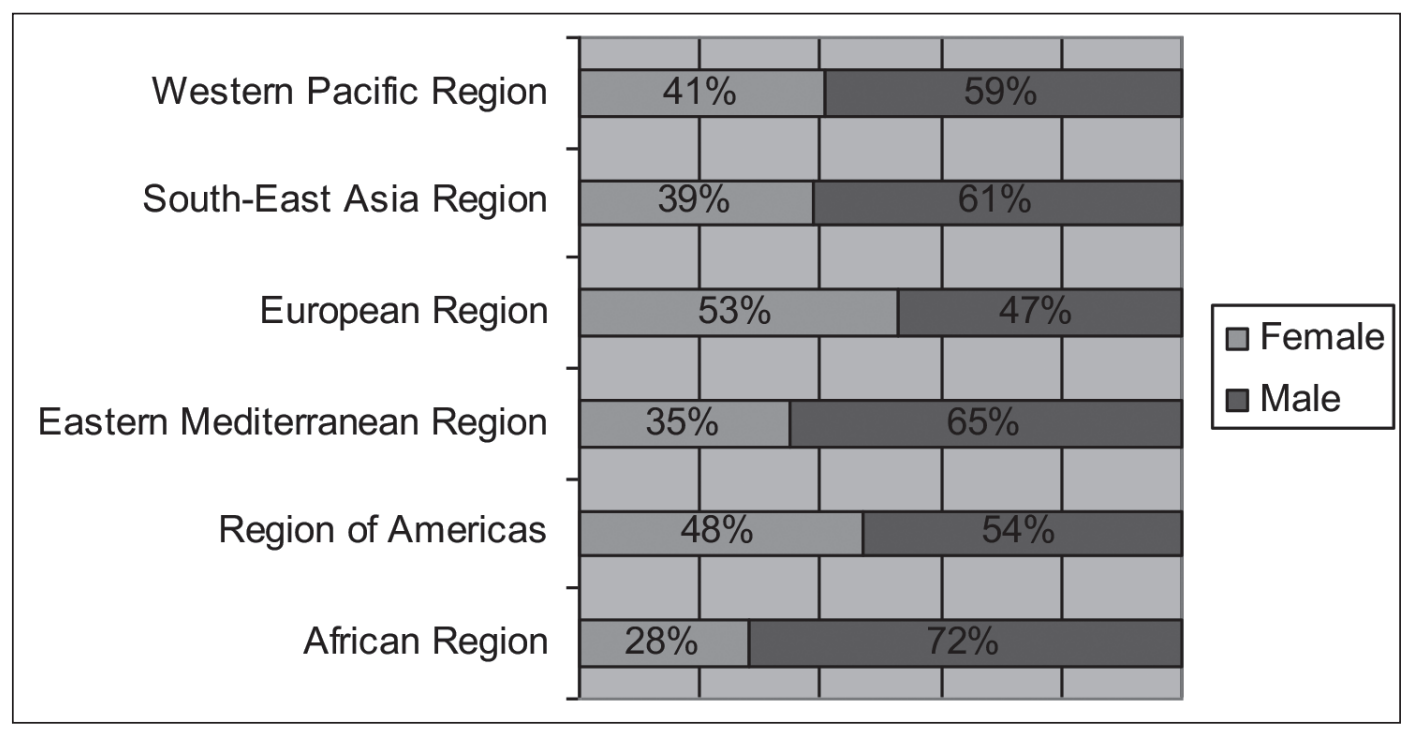

Fig. 1. Distribution of physicians by gender. Source: Data from National Health Workforce Accounts

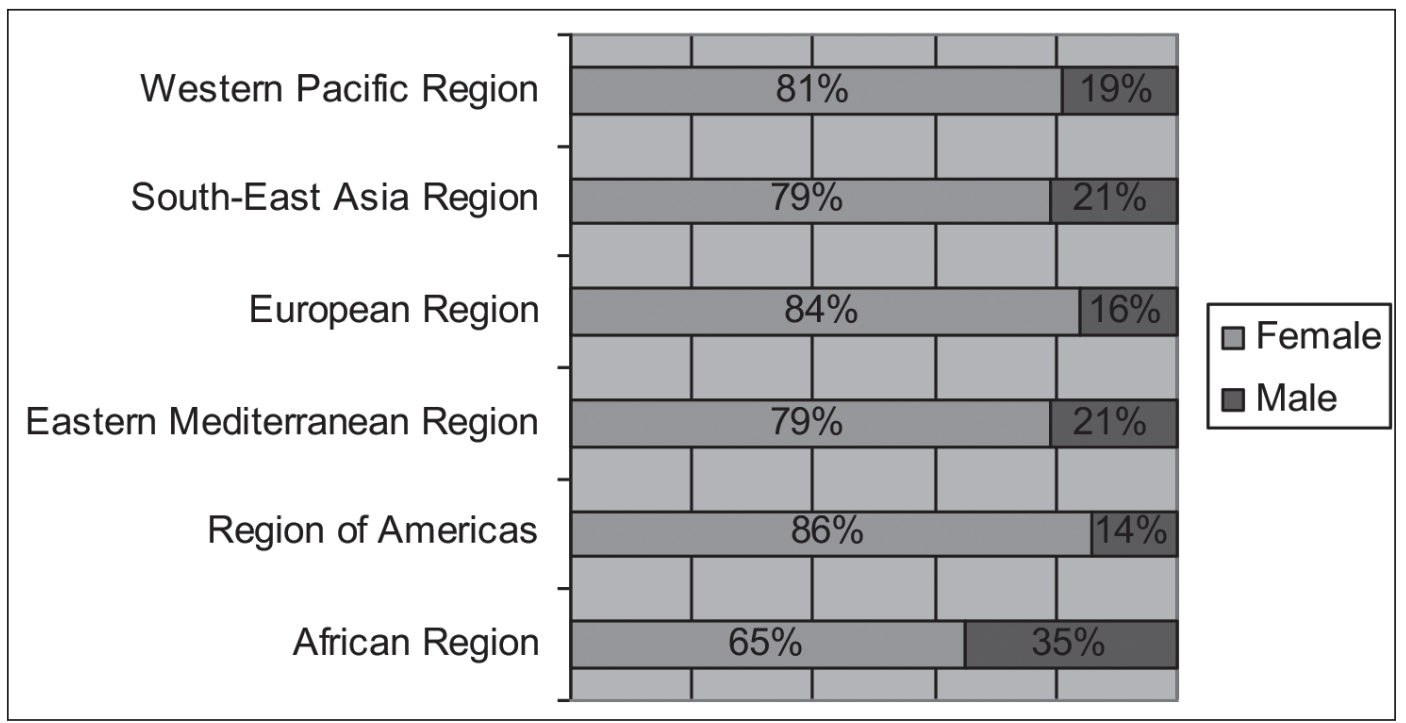

Fig. 2. Distribution of nurses by gender. Source: Data from National Health Workforce Accounts

statistics that demonstrate the nature of gender inequality in healthcare in terms of employment and remuneration.

\section{REVIEW AND DISCUSSION}

Totally, there are 234 million healthcare employees around the world [10], and the share of women's employment in healthcare is $67 \%$ of the total number of healthcare employees around the world [11]. In 2017 almost half of all physicians in countries of the Organization for Economic Cooperation and Development were women [12].

The World Health Organization (WHO) conducted a study [13] on gender and job differentiation in healthcare which had to show occupational segregation in the branch of medicine.

According to the graphs (Fig. 1 and Fig. 2), it's noticeable that in majority of regions, male healthcare employees make up the majority of physicians. Instead of that, women make up the majority of employees as nurses.
In the majority of countries, healthcare employees earn below the average wage in the country, and the wages of low-skilled employees in healthcare often have a basic minimum amount [14]. In 2018 the International Labour Organization (ILO) presented an analysis of the average wage in the healthcare sector in the report "Global wage report 2018/19" [15]. The results of the report showed significant gender gaps relating to wages, working hours and gender discrimination in the branch of medicine.

The analysis (Fig. 3) shows that, in general, women who works in healthcare sector earn $28 \%$ less than men. Working during the same working hours, but in different positions, women earn $21 \%$ less than men. Doing the same job during the same working hours, women earn $11 \%$ less than men in the healthcare sector.

Imbalance of employment and remuneration in the public or private healthcare sector is also highly indicative [16]. In private healthcare sector men are more likely than 


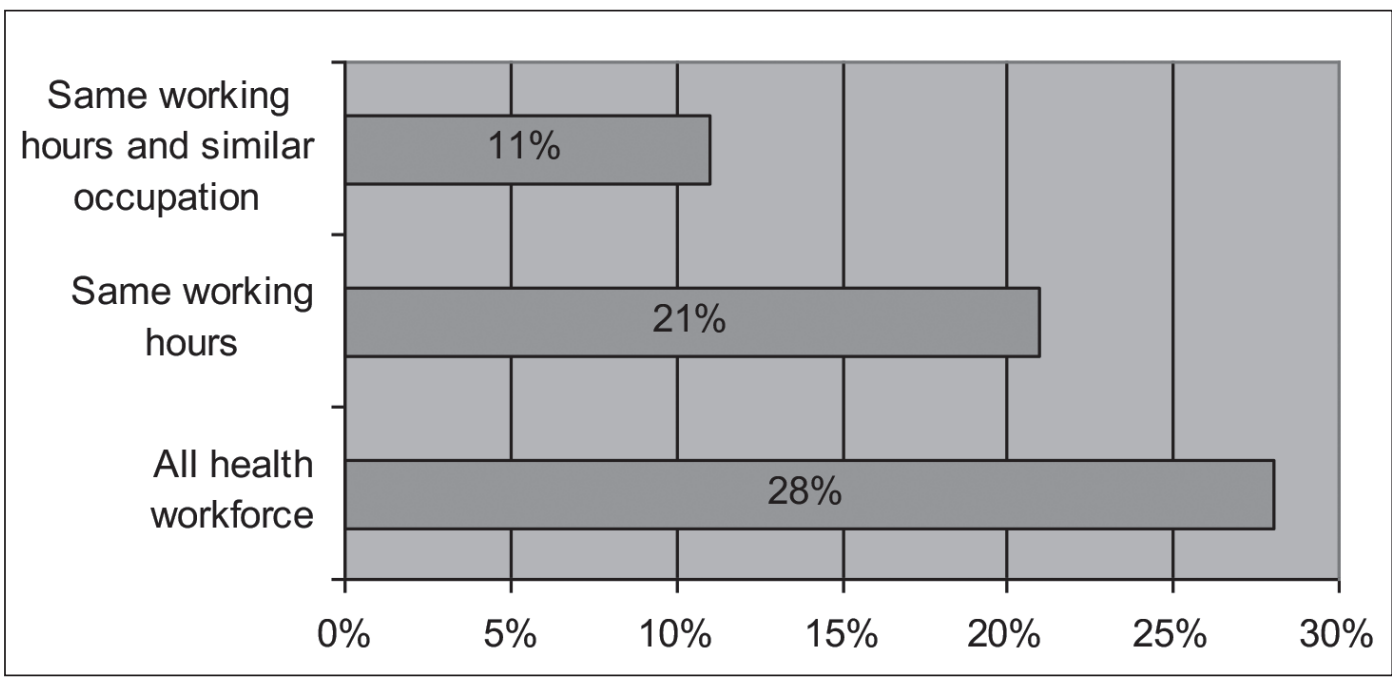

Fig. 3. Gender remuneration gap among healthcare employees as a percentage of men's wages. Source: Data from IL0. Global wage report 2018/19

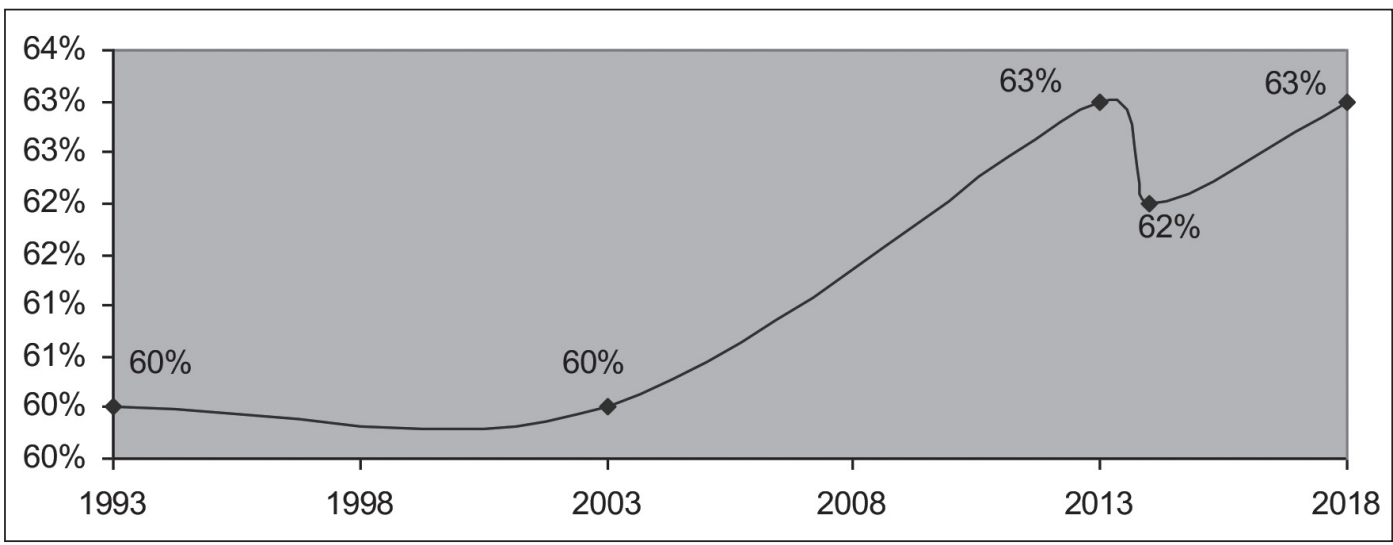

Fig. 4. Distribution of physicians by gender in Ukraine, 1993/2018, \%. Source: Data from State Statistics Service of Ukraine.

women work as physicians (49.2\% and $39.2 \%$ respectively), that creates a pay gap. Instead of that, women are often employed in the private healthcare sector as nurses $(81.8 \%$ and $53 \%$ respectively) and mostly earn less than men.

As a member of the world medical community, Ukraine has similar trends related to gender imbalance in healthcare which can be observed taking into account some national characteristics.

In 2018 the most (around two thirds - 63\%) of physician positions in Ukraine were occupied by women (Fig. 4), that exceeds the global rate (40\%) of women's representation on such positions. The number of female nurses also exceeds the global rate (79\%) and was $94 \%$ in 2018 (Fig. 5). At the same time, the structure of physicians and nurses by gender has not changed since $1993.51 \%$ of managers positions at healthcare institutions occupied by women [17].

Given the quantative advantage of women in Ukrainian healthcare, the wages of women and men in the branch of medicine differ in the direction of gender inequality. However, according to the reports of the State Statistics Service of Ukraine, we can note the positive dynamics of women wages over the last decade.

The indicators (Fig. 6) illustrate that the difference between the wages of women and men in the branch of medicine in Ukraine is less than the world's average. In 2018 the correlation of the average wage of women and men in this sector was $28 \%$ around the world and $9.3 \%$ in Ukraine. Moreover, the dynamics of levelling Ukrainian indicators of the average wage of women and men in healthcare is positive (from 2003 to 2020 the gap in the wages amount of women and men in the of healthcare decreased by $7.3 \%)$. At the same time, it does not prove real gender equality in Ukrainian healthcare sector. In the first quarter of 2020, the average monthly wage in the healthcare sector of Ukraine was 7901 Ukrainian hryvnia, which is about 290 EUR. This amount is less than twice exceeding the amount of minimum wage which is guaranteed by Ukraine and payed for unqualified work. We can assume, that mainly for such reason, men who have medical education or certification often prefer private practice or strive work in private healthcare facilities (unfortunately, we do not possess statistical data on this issue). Hence, because of such situation, not all positions of medical employees at Ukrainian state healthcare institutions are occupied and there is a lack of professionals in state healthcare sector.

The conducted study confirmed the hypothesis that employment in the medical branch is predominantly female. At the same time, there is a significant gender gap in 


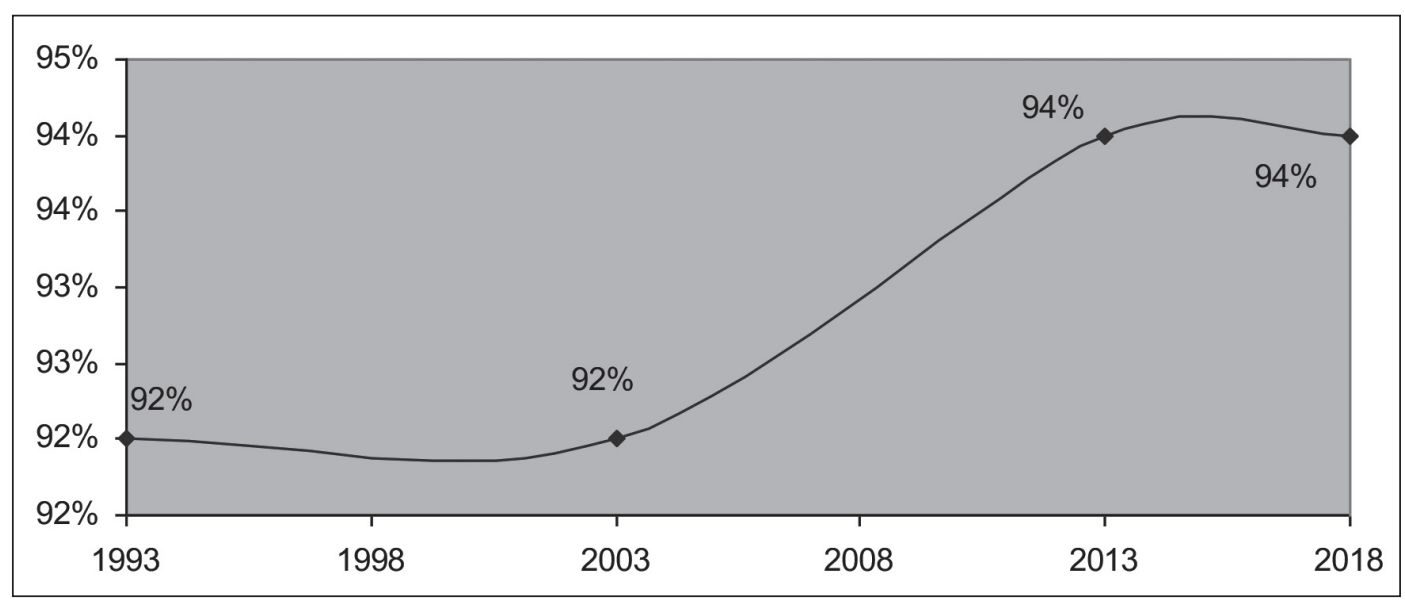

Fig. 5. Distribution of nurses by gender in Ukraine, 1993/2018, \%. Source: Data from State Statistics Service of Ukraine.

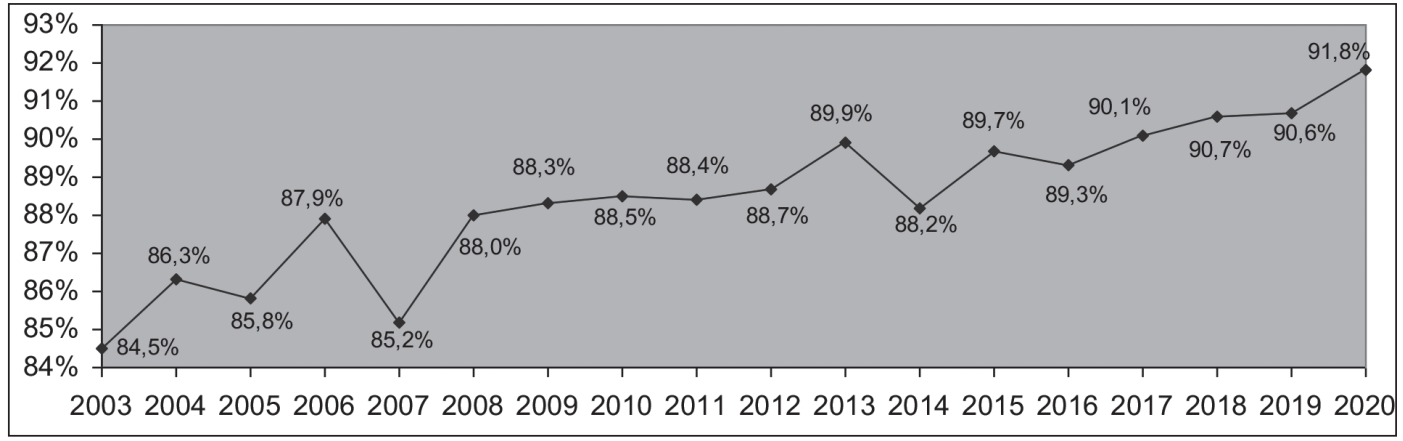

Fig. 6. Correlation of the average salary of the women and men in healthcare sphere, 2003/2020,\%. Source: Data from State Statistics Service of Ukraine.

women's attitudes towards employment in medicine. Men make up the majority of physicians and women make up the majority of nurses. Men have higher potential career opportunities to get a job in the private healthcare sector at the level of qualified medical professionals, and women have more risks to get low-paid medical jobs in the private sector, which are usually fixed-term.

The global pay gap among healthcare employees can be explained by several reasons:

1) different duration of work for men and women (women are less likely than men being full-time employed: among physicians, women work 4.2 hours per week less than men; among nurses -3.5 hours per week less than men in same positions; women-dentists - 3.7 hours per week less than men [16]). This is primarily connected with women's family duties and housework in addition to their professional responsibilities. $82 \%$ of women-physicians name work and family life balance as a major challenge in the branch of medicine. $71 \%$ of women who are working in healthcare sector indicate that their careers limit the duration of time which they can spend with their families. As a result, women from healthcare sector have great difficulty with work-life balance, therefore women more likely than men move to part-time jobs, refuse to take part in certification trainings or quit their jobs to take care about their families;

2) occupational differentiation between men and women as well as a set of other factors related to underestimation of women holding management positions (twice as many management positions in healthcare are held by male physicians than women), less chances of career promotion (male physicians are more likely have higher level of qualification than women). $70 \%$ of men who are employees in healthcare sector believe that their gender opportunities are the same as for women. At the same time, only $49 \%$ of women feel the same. Women are much more likely to consider their career opportunities worse than men's ( $49 \%$ of women versus $13 \%$ of men).

3) gender discrimination, especially the cases of sexual harassment of women in the healthcare sector. $12 \%$ of women reported that they had never encountered any form of sexual harassment while they are working in the medical branch versus $38 \%$ of men. Only $7 \%$ of women say that the employees in healthcare sector do not have problems with sexual harassment. Another factor that confirms gender discrimination in the medical branch is the different perceptions of women and men in healthcare. $69 \%$ of men believe that women and men are treated equally at healthcare facilities, but only $34 \%$ of women agree with this fact. $63 \%$ of women believe that men are respected more than women. $87 \%$ of women health professionals believe that patients treat them differently than men [18].

The Ukrainian healthcare sector might be called "women's", which is explained by the next reasons. The length of life of women is seven years longer than the life of men in Ukraine. Such situation has a serious impact on employment in healthcare sector, where the common practice to 
continue working after retirement age exists in case with female healthcare employees (25\% of physicians and more than $10 \%$ of nurses are retired employees) [19]. However, the most obvious indicator is not the age structure of women's employment in healthcare, but the amounts of their wages.

In Ukraine wages of women in healthcare are only $11 \%$ lower than of men. However, this dynamic is a formal outline of progress in ensuring gender equality in Ukrainian healthcare sector. In fact, given the predominant representation of women physicians and nurses among all employees, a minority of women generally receive higher wages than men. Such discrepancy exists primarily because of the very high representation of women at lower-paid positions, e.g. nurses. Maintaining the quantative advantage of women and small correlation between women's and men's wages in the medical branch does not guarantee them decent employment opportunities and wages.

For such reasons, the progressive indicators of gender equality in Ukraine in terms of the number of positions occupied by healthcare employees and the level of their remuneration are illusory. Conversely, they discourage women to work in healthcare sector reducing their economic and social status. As we may see, the global trend of low remuneration in healthcare which reduces the socio-economic status of healthcare employees and produce gender inequality and sets the risks associated with the effective provision of health care and the shortage of qualified professionals in the branch of medicine has being implemented in Ukraine.

Lowering the prestige of work of women in healthcare and segregation in terms of profession means that the gender gap in remuneration and wages in this sector is significant. Given the large number of women employed in healthcare sector, it also has a strong impact on the gender pay gap in the economy generally. Reduction of male employment in healthcare sector is associated with the attitudes in society about "women's" skills and the stereotype that women can sell their workforce for less reward. In Europe the most low-paid positions are occupied by women and scientific researches show that only the fact of employment in a female-dominated profession can reduce wages by $9 \%$ [20]. The wages which are paid in healthcare are the evidences of the overall low cost and low prestige of work in healthcare sector. Moreover, they create the preconditions for significant gender inequality in this sphere.

The availability of medical services and quality of future workforce in healthcare sector significantly depend on increased wages. Instead of this, the current trends of low wages in healthcare produce a significant shortage of qualified medical personnel. In 2019 the shortage of physicians and nurses at Ukrainian public healthcare institutions was $88 \%$ and $93 \%$ respectively [19]. It is estimated that the global shortage of healthcare employees by 2030 will be up to 18 million of physicians and nurses [1]. At the same time, more favourable working conditions and a decent level of remuneration will contribute to the prestige and attractiveness of work in the medical sphere.

\section{CONCLUSIONS}

1. According to global and Ukrainian indicators, the healthcare sector mainly consists of women in the structure of employees. Women are mostly employed on nursing positions. The majority of physicians are men. There is another trend in Ukraine when women predominate among physicians. The wide representation of women in healthcare does not prevent the presence of gender inequality among healthcare employees, in particular, in terms of employment and remuneration. The main reasons causing gender inequality in healthcare are: different duration of work for men and women; family responsibilities as an addition to women professional activities; occupational differentiation between men and women due to underestimation of women on management positions; less opportunities for career promotion and certificate trainings; gender discrimination (in particular, sexual harassment, different perceptions of professionals).

2. In order to effectively reduce gender inequalities in healthcare, the following legal means should be established and implemented both in international and national law: 1) remove barriers to full-time employment of women, support women's career growth and gender parity on management positions in healthcare; 2) establish a minimum wage for healthcare employees which will be equal to the average wage in the country and will increase depending on the qualifications and productivity of healthcare employees; 3 ) establish the minimum wage of healthcare employees in rural areas and healthcare facilities that are experiencing a shortage of staff, twice as much as the average wage in the region; 4) establish a specific entity (e.g. commission) to consider cases of gender discrimination against women in healthcare; 5) introduce an audit of gender equality in healthcare; 6) establish bonuses for women-healthcare employees who have children or other dependants; 7) develop recommendations to national governments to increase the number of legal norms that will guarantee equal rights and opportunities for women and men in healthcare sector, indicating the specific terms of their fixing in collective agreements, as well as develop and make proposals to increase the number of relevant norms in the Sectoral Agreement in healthcare sector.

\section{REFERENCES}

1. WHO. Regional Office for Europe "Data and statistics": World Health Organization. Available from: https://www.euro.who.int/en/healthtopics/communicable-diseases/hivaids/data-and-statistics [reviewed 2020.08.12].

2. WHO. Global Strategy on Human Resources for Health:Workforce 2030. World Health Organization; 2016:24. Available from: https://www.who. int/hrh/resources/globstrathrh-2030/en/ [reviewed 2020.08.12].

3. Pashkov V, Tatsiy V, Gutorova N. Legal aspects of cancer diseases prophylactics: patient's rights context. Wiadomosci Lekarskie. 2017; 70: 1108-1114.

4. Hempenstall A, Tomlinson J, Bismark M. Gender inequity in medicine and medical leadership. MJA. 2019; 211 (10): 475-476. 
5. Ludwig S, Kurmeyer C, Gross M. A Successful Strategy to Integrate Sex and Gender Medicine into a Newly Developed Medical Curriculum. Journal of Women's health. 2015; 24: 996-1006.

6. Barr D. Gender Differences in Medicine. From Medical School to Medicare. Mayo Foundation for Medical Education and Research. 2017; $6(92): 854-857$.

7. Spencer $E$, Deal A, Pruthi N. Gender differences in compensation, job satisfaction and other practice patterns in urology. J Urol. 2016; 195 (2): 450-455.

8. Willett L, Halvorsen A, Chaudhry S. Gender Differences in Salary of Internal Medicine Residency Directors: A National Survey. The American Journal of Medicine. 2015; 6 (128): 660-665.

9. Read S, Butkus R, Weissman A. Compensation disparities by gender in internal medicine. Ann Intern Med. 2018; 169(9): 658-661.

10. ILO. Report for discussion at the Tripartite Meeting on Improving Employment and Working Conditions in Health Services. Geneva: International Labour Organization; 2017: 50. Available from: https:// www.ilo.org/wcmsp5/groups/public/---ed_dialogue/---sector/ documents/publication/wcms_548288.pdf [reviewed 2020.08.12].

11. Buchan J, Dhillon I, Campbell J. Health employment and economic growth: an evidence base. Geneva: World Health Organization; 2017: 455. Available from: https://www.who.int/hrh/resources/WHO-HLCReport_web.pdf?ua=1 [reviewed 2020.09.10].

12. OECD. Health at a Glance. Organization for Economic Co-operation and Development; 2019: 174. Available from: https://www.oecdilibrary.org/social-issues-migration-health/health-at-a-glance2019_4dd50c09-en [reviewed 2020.09.10].

13. WHO. National Health Workforce Accounts data include country reported indicators, OECD statistics, Labour Force Survey (LFS). Geneva: World Health Organization; 2016: 25. Available from: https://www.who. int/hrh/documents/handbook_health_workforce_14a.pdf?ua=1 [reviewed 2020.09.10].

14. Pillinger J. Pay and the gender wage gap in health and social care. Report of EPSU Study on pay in the care sector in relation to overall pay levels and the gender pay gap in different countries in the European Union; 2010: 55. Available from: https://www.epsu.org/article/payand-gender-wage-gap-health-and-social-care [reviewed 2020.08.11].

15. ILO. Global wage report 2018/19: what lies behind gender pay gaps. Geneva: International Labour Organization; 2018: 172. Available from: https://www.ilo.org/wcmsp5/groups/public/---dgreports/---dcomm/--publ/documents/publication/wcms_650553.pdf[reviewed 2020.08.11].

16. Boniol M, Mclsaac M, Xu L et. al. Gender equity in the health workforce: Analysis of 104 countries. WH0. 2019; 9.
17. MH. Pragnemo do gendernoyi rivnosti u sferi oxorony zdorov'ya [We strive for gender equality in healthcare]. Ministry of Healthcare of Ukraine: 2017. Available from: https://moz.gov.ua/article/news/ pragnemo-do-gendernoi-rivnosti-u-sferi-ohoroni-zdorovja [reviewed 2020.08.11] (Ua)

18. Saley C. Female physicians receive less respect and more harassment than their male counterparts. 2019. Available from: https://www. un.org/womenwatch/daw/csw/nursing.htm [reviewed 2020.09.10].

19. Bogdan D, Boyko A, Vakilkova A et. al. Kadrovi resursy systemy oxorony zdorov'ya v Ukrayini [Human resources of the healthcare system in Ukraine]. USAID Healthcare Reform Support Project; 2019: 133. (Ua).

20. Forth J, Milward N. The Determinants of Pay Levels and Fringe Benefit Provision in Britain. London: National Institute of Economic and Social Research. 2000: Discussion Document No 171: 76. Available from: http://citeseerx.ist.psu.edu/viewdoc/ download?doi=10.1.1.32.5410\&rep=rep1\&type=pdf [reviewed 2020.09.10].

\section{ORCID and contributionship:}

Olena Y. Kostiuchenko: 0000-0002-8244-3563 A, E, F

Olha V. Hots-Yakovlieva: 0000-0002-7217-7329 ${ }^{A, D}$

Julia O. Sayenko: 0000-0002-0798-5370 B, C

\section{Conflict of interest}

The Authors declare no conflict of interest.

\section{CORRESPONDING AUTHOR Olena Y. Kostiuchenko}

Department of Legal Ensuring of Business Security, Kyiv National University of Trade and Economics,

19 Kyoto str., Kyiv, Ukraine, 02156.

tel: +380502251576

e-mail:A09111975@i.ua

Received: 01.09 .2020

Accepted: 27.11 .2020

A - Work concept and design, B - Data collection and analysis, C - Responsibility for statistical analysis, D-Writing the article, $\mathbf{E}$-Critical review, $\mathbf{F}$ - Final approval of the article 